\title{
BKMT KOTA JAYAPURA DALAM MENGEMBANGKAN MAJELIS TA'LIM TINGKAT MESJID
}

\author{
Zulihi $^{[1]}$, Muhamad Yusuf ${ }^{[2]}$ \\ ${ }^{[1,2]}$ IAIN Fattahul Muluk Papua
}

\begin{abstract}
ABSTRAK
BKMT Kota Jayapura dalam menjalankan tugasnya pada kenyataannya masih terdapat Majelis Ta'lim yang belum terpantau oleh BKMT Kota, bahkan dalam pelaksanaaan kegiatan keagamaan BKMT Kota kadang tidak melibatkan majelis Ta'lim tingkat Mesjid, sehingga konstrbusi yang ditimbulkan BKMT Kota Jayapura belum dirasakan. Tujuan penelitian untuk mengetahui peran pengurus dalam mengembangkan organisasi, bentuk kegiatan dilakukan, dan faktor penghambat kegiatan yang dilakukan BKMT Kota Jayapura. Pengurus BKMT Kota Jayapura diharapkan mampu melaksanakan komunikasi dengan pendiri BKMT Kota Jayapura sehingga proses pertukaran, pemahaman informasi yang dilakukan antara pengurus dengan pendiri BKMT Kota. Pentingnya komunikasi norma, nilai dalam tindakan anggotanya melakukan kegiatan, tidak terdapat penghargaan bagi pengurus yang memiliki sumbangan besar terhadap organisasi, merencanakan tenaga pengurus, mengidentifikasikan pekerjaan, menempatkan anggota baru yang diambil dari BKMT tingkat distrik, melaksanakan sosialisasi pada pengurus baru tentang tugas, tanggungjawab yang harus dilaksanakan. Pelatihan dan pengembangan yang dilakukan untuk pengurus BKMT terkendala sumber dana yang tersedia, adanya kontak antara pengurus BKMT Kota Jayapura agar saling mengenal sehingga memudahkan pengurus saling berhubungan, pengambilan keputusan dilakukan secara perorangan, namun ada juga yang dilakukan secara kelompok. Pengambilan keputusan yang dilakukan oleh pimpinan BKMT berdasarkan pertimbangan tertentu, atau berdasarkan sifat urgennya, koordinasi dilakukan jika terdapat pekerjaan yang dilakukan bersama, melaksanakan pertukaran personal baik diantara pengurus dalam tubuh BKMT Kota maupun dengan pengurus yang ada di propinsi atau BKMT yang ada pada tingkat distrik.
\end{abstract}

Kata Kunci: Organisasi, BKMT, Majelis Ta'lim 


\begin{abstract}
BKMT Jayapura in carrying out its duties in fact there is still a majelis ta'lim has not been tracked by BKMT, even in the implementation of religious activities BKMT sometimes does not involve Majelis Ta'lim of Mosque level, so the contribution posed BKMT Jayapura is not yet felt. The research aims to determine the role of managers in developing the organization, the form of activities undertaken, and the inhibitory factor of activities conducted by BKMT Jayapura. The management of BKMT Jayapura is expected to be able to conduct communication with the founder of BKMT Jayapura so that the exchange process, understanding the information conducted between the Board with the founder of BKMT. The importance of norms communication, the value in the actions of its members conducting activities, there is no appreciation for managers who have a large contribution to the organization, planning the personnel, identifying the work, placing new members taken from the district level BKMT, implementing socialization on the new officers on the task, responsibility to be carried out. Training and development conducted for BKMT managers constraints of available funds, the contact between the board of BKMT Jayapura to know each other so as to facilitate managers interconnected, decision making is done individually, but some are done in a group. Decision making by the leadership of BKMT based on certain considerations, or based on the properties of its urgency, coordination is done if there is work done together, carrying out personal exchange between the managers in the body BKMT and with the caretaker in the province or BKMT at the district level.
\end{abstract}

Keywords: Organization, BKMT, Majelis Ta'lim

\title{
A. PENDAHULUAN
}

Di era globalisasi sekarang ini dimana penuh dengan berbagai persaingan diberbagai bidang IPOLEKSOSBUD HANKAM memaksa negeri ini untuk terus berbenah diri agar tidak tertinggal dengan negara lainnya. Dengan semakin meningkatnya kompleksitas kehidupan masyarakat yang menyangkut berbagai aspek, pemikiran tentang modernisasi pun tidak lagi hanya mencakup bidang ekonomi dan industri, melainkan telah merambah ke seluruh aspek yang dapat mempengaruhi kehidupan masyarakat. Oleh karena dalam proses modernisasi itu terjadi suatu proses perubahan yang mengarah pada perbaikan. Namun Terkadang pembangunan fisik tidak seiring dengan pembangunan mental manusia.

Pembangunan merupakan usaha yang dilakukan secara sadar, teratur dan berencana, yang memiliki arah dan tujuan yang ingin dicapai menuju ke arah yang lebih baik, meliputi berbagai aspek kehidupan manusia. Proses pembangunan terjadi di semua aspek kehidupan masyarakat, ekonomi, sosial, budaya, politik, yang berlangsung pada level makro (nasional) dan mikro (commuinity/group). Makna penting pembangunan adalah adanya kemajuan/perbaikan (progress), pertumbuhan dan diversifikasi. Jika kita berbicara tentang pembangunan, maka tidak akan terlepas dengan rangkaian 
usaha melakukan suatu perubahan ke arah yang lebih baik. Dengan demikian dapat dikatakan bahwa pada dasarnya pembangunan tidak dapat dipisahkan dari pertumbuhan, dalam arti bahwa pembangunan dapat menyebabkan terjadinya pertumbuhan dan pertumbuhan akan terjadi sebagai akibat adanya pembangunan. Dalam hal ini pertumbuhan dapat berupa pengembangan/perluasan (expansion) atau peningkatan (improvement) dari aktivitas yang dilakukan oleh suatu komunitas masyarakat.

Pengembangan organisasi merupakan salah-satu contoh kecil pembangunan yang dilakukan oleh sekelompok orang guna lebih meningkatkan organisasi yang dijalankannya. Dewasa ini model organisasi keagamaan mulai merebak di negara ini, mulai dari yang dikelola oleh kaum laki-laki maupun perempuan, bahkan dikelola secara bersama-sama antara laki-laki dan perempuan. Salah satu organisasi keagamaan yang digerakkan oleh kaum perempuan adalah BKMT (Badan Koordinasi Majelis Ta'lim) yang mengkoordinir majelis-majelis $\mathrm{Ta}^{\prime} \mathrm{lim}^{1}$ yang ada disekitarnya. Walaupun keberadaan Majelis ta'lim seringkali dikonotasikan sebagai media yang rentan dipolitisasi. Secara literal majelis ta'lim berarti 'tempat pembelajaran' yang merupakan wadah di mana suatu kelompok masyarakat (laki-laki ataupun perempuan) bertemu untuk belajar dan mendalami ajaran agama. Majelis ta'lim hidup bersifat nonformal dan tumbuh semarak di seluruh pelosok tanah air baik melalui organisasi-organisasi keagamaan maupun organisasi-organisasi masyarakat.

Begitupula di Kota Jayapura, dimana terdapat BKMT Kota yang mengkoordinir dan merupakan perpanjangan tangan dari seluruh Majelis Ta'lim di Kota Jayapura, dimana BKMT Kota memiliki organisasi yang jelas, memiliki struktur organisasi, tugas, fungsi dan tanggungjawab serta memiliki alokasi dana untuk melaksanakan kegiatan-kegiatan yang telah dijadwalkan. Pada kenyataannya di Kota Jayapura masih terdapat Majelis Ta'lim yang belum terpantau oleh BKMT Kota, bahkan dalam pelaksanaaan kegiatan keagamaan BKMT Kota terkadang tidak melibatkan majelis Ta'lim tingkat Mesjid, sehingga konstrbusi yang ditimbulkan oleh BKMT Kota Jayapura belum dirasakan oleh Majelis Talim tingkat Mesjid. Menjadi sebuah pertanyaan, untuk apa dibentuk BKMT? Untuk apa dana kegiatan yang diperoleh digunakan oleh BKMT Kota Jayapura? Padahal dana-dana yang diperoleh BKMT Kota Jayapura setiap tahunnya jelas adanya. Dengan demikian maka dapat dilihat adanya penekanan sekelompok kaum perempuan yang berada di dalam lingkup BKMT Kota yang memperoleh dana namun tidak adanya penyaluran kegiatan ke sekelompok perempuan mejelis ta'lim dibawahnya. Dana tersebut digunakan hanya untuk kegiatan ibu-ibu yang ada di BKMT Kota tanpa adanya partisipasi dari Majelis Taklim yang ada di mesjid-mesjid.

Tujuan penelitian yang dilakukan adalah untuk mengetahui tentang peran pengurus dalam mengembangkan organisasi BKMT di Kota Jayapura, bentuk dari kegiatan-kegiatan yang selama ini dilakukan oleh BKMT Kota

${ }^{1}$ Menurut bahasa Majelis Ta'lim berasal dari kata bahasa Arab yaitu dari kata majlis yang artinya tempat duduk. yang artinya tempat duduk, dan ta'lim yang artinya pengajaran. Jadi majelis ta.lim adalah tempat untuk mengadakan pengajaran dan pengajian agama Islam. Pengertian majelis lainnya adalah tempat berkumpulnya sekelompok orang untuk melakukan semua kegiatan, sehingga dikenal sebagai majelis semua majelis syuro, majelis hakim dan sebagainya. (Koordinasi Da.wah Islam (KODI) DKI Jakarta,1990:5). 
Jayapura dan faktor penghambat dari kegiatan-kegiatan yang dilakukan oleh BKMT Kota Jayapura.

Amalia Dian Khoir. 2011. Pembinaan Keagamaan Bagi Ibu-ibu Melalui Majelis Ta'lim di Desa Ngijo Kecamatan Karangploso Kabupaten Malang. Universitas Islam Negeri (UIN) Maulana Malik Ibrahim Malang. Pembinaan keagamaan melalui majelis ta'lim adalah majelis ta'lim yang khusus diselenggarakan untuk mewadahi kaum perempuan (ibu-ibu) di Desa Ngijo Kecamatan Karangploso Kabupaten Malang, sehingga mereka masih bisa terus belajar khususnya pengetahuan agama. Tujuan penelitian: 1. Untuk mengetahui kegiatan yang ada dalam pembinaan keagamaan; 2. Untuk mengetahui materi yang disampaikan dalam pembinaan keagamaan; 3. Untuk mengetahui bagaimana pelaksanaan pembinaan keagamaan. Penelitian ini menggunakan pendekatan deskriptif kualitatif sebagai prosedur penelitian yang menghasilkan data berupa kata-kata tertulis. Teknik pengumpulan data menggunakan: Observasi, interview dan dokumentasi. Informannya adalah Ketua Majelis Ta'lim, Ketua Fatayat, Pembina Majelis Ta'lim, Kepala Desa, Peserta (anggota) majelis ta'lim. Analisis data menggunakan triangulasi sumber. Hasil penelitian : 1. Kegiatan yang ada dalam pembinaan keagamaan bagi ibu-ibu melalui majelis ta'lim berbeda dengan majelis ta'lim yang ada di Desa lain, karena dalam majelis ta'lim ini dimulai dengan pembacaan istighosah dan di tutup dengan sholat tasbih, kegiatan intinya adalah pengajian (ceramah agama); 2. Materi yang disampaikan dalam majelis ta'lim ini meliputi Fiqih, akhlak, muamalah, ketauhidan dan ibadah; 3. majelis ta'lim ini sudah berjalan sejak tahun 2006, pembinaan keagamaan melalui majelis ta'lim ini dilaksanakan setiap hari sabtu malam minggu, waktunya adalah pukul 21.00 wib sampai selesai, tempat pelaksanaannya berpindah-pindah dari masjid satu ke masjid yang lain. Pesertanya tidak dibatasi karena belum ada buku absen, dan kendala yang dihadapi ibu-ibu dalam kegiatan ini adalah karena tempatnya yang berpindahpindah dan waktu yang terlalu malam. (http://lib.uinmalang.ac.id/thesis/introduction/o7110131-dian-khoir-amalia.pdf)

Majelis Taklim Asy Syifa: Potret Majelis Taklim Dalam Komunitas Muslim Muallaf Di Bali Oleh : Nyayu Khodijah (2019) Penelitian ini bertujuan memperoleh data maupun informasi yang lengkap, mendalam, dan komprehensif tentang: fungsi yang dijalankan, manajemen, materi, dan proses pembelajaran pada Majelis Taklim Asy Syifa. Penelitian menggunakan pendekatan kualitatif dengan metode fenomenologi. Teknik pengumpulan data yang digunakan : observasi, wawancara, dan studi dokumentasi, sedang teknik analisis data yang digunakan adalah teknik analisis deskriptif kualitatif. Hasil penelitian : majelis taklim Asy Syifa menjalankan fungsi sebagai lembaga pendidikan yang memberikan pengajaran agama dasar bagi para jamaahnya dan penyelenggaraannya tidak jauh berbeda dengan proses pembelajaran yang berlangsung di sekolah/madrasah atau di Taman Pendidikan Al Qur'an (TPA). Proses penyelenggaraannya, majelis taklim dipengaruhi kondisi sosial budaya dan ekonomi jamaah dan ustadz/ahnya, nampak dari pemilihan materi pelajaran, proses pembelajaran, dan manajemennya. Materi pelajaran yang dipilih : materi utama ajaran Islam pada level dasar. Proses pembelajarannya lebih banyak didominasi oleh guru sebagai sumber belajar tunggal. Manajemen yang diterapkan adalah pola manajemen tunggal, di mana pimpinan merangkap 
juga sebagai sekretaris dan bendahara majelis taklim. (http://dualmode.kemenag.go.id/acis11/file/dokumen/d14.NyayuKhodijah.pdf)

Perbedaan dengan penelitian yang dilakukan oleh peneliti terletak pada: Lokasi penelitian yang dilakukan di Kota Jayapura, penggunaan beberapa teori yang berbeda, serta metode fenomenologi social yang digunakan, serta hasil penelitian yang berbeda, dan lebih berfokus pada peran pengurus serta factor penghambat keberlangsungan BKMT di Kota Jayapura.

Peranan atau istilah lain "Role" adalah tindakan yang diberikan atau dimiliki seseorang berupa power guna memainkan kapasitas pribadinya secara maksimal melalui kerja sama dengan orang lain agar dapat mencapai tujuan dari kerja sama tersebut. Menurut ensiklopedia Indonesia (1994:265), bahwa peranan seseorang yang berstatus pemimpin dapat berwujud antara lain:

1. Sebagai Guru

Memberi informasi, membantu menerapkan dan memecahkan masalah, mengajarkan pengetahuan baru, dan ketrampilan kepada anggotanya;

2. Sebagai Pembimbing

Memberi nasihat dan dorongan (motivasi) dalam hal kerjasama dan usaha;

3.. Sebagai Penggerak

Menanamkan kesadaran akan arti pentingnya berkelompok dan mendorong semangat kerjasama dan menjaga agar tujuan tercapai;

4. Sebagai Pemimpin

Berkewajiban merumuskan dan mengorganisasikan aspirasi kelompok kedalam kegiatan yang terarah serta waspada terhadap keadaan yang mempengaruhi kesejahteraan anggotanya;

5. Sebagai Teladan

Memberikan pola panutan dan contoh bagi masyarakat.

Edgar Schein dalam Jhon M. Ivancevich, Robert Konopaske dan Michael T. Matteson (2006:45), mengatakan : "Suatu pola dari asumsi dasar-yang diciptakan, ditemukan, atau dikembangkan oleh kelompok tertentu saat belajar menghadapi masalah adaptasi eksternal dan integrasi internal-yang telah berjalan cukup baik untuk dianggap valid dan oleh karena itu, untuk diajarkan kepada para anggota baru sebagai cara yang benar untuk berpersepsi, berfikir, dan berperasaan sehubungan dengan masalah yang dihadapi”. Jhon M. Ivancevich, Robert Konopaske dan Michael T. Matteson (2006:46), mengatakan : "Karena budaya organisasi melibatkan ekspektasi, nilai dan sikap bersama hal tersebut memberikan pengaruh pada individu, kelompok, dan proses organisasi. Budaya organisasi terhadap anggota menunjukkan bahwa budaya organisasi menyediakan dan mendorong suatu bentuk stabilitas organisasi”.

Evolusi budaya yang positif dikembangkan oleh Warren Gross dan Shula Shichman dalam Jhon M. Ivancevich, Robert Konopaske dan Michael $\mathrm{T}$. Matteson (2006:49) digambarkan sebagai berikut: 


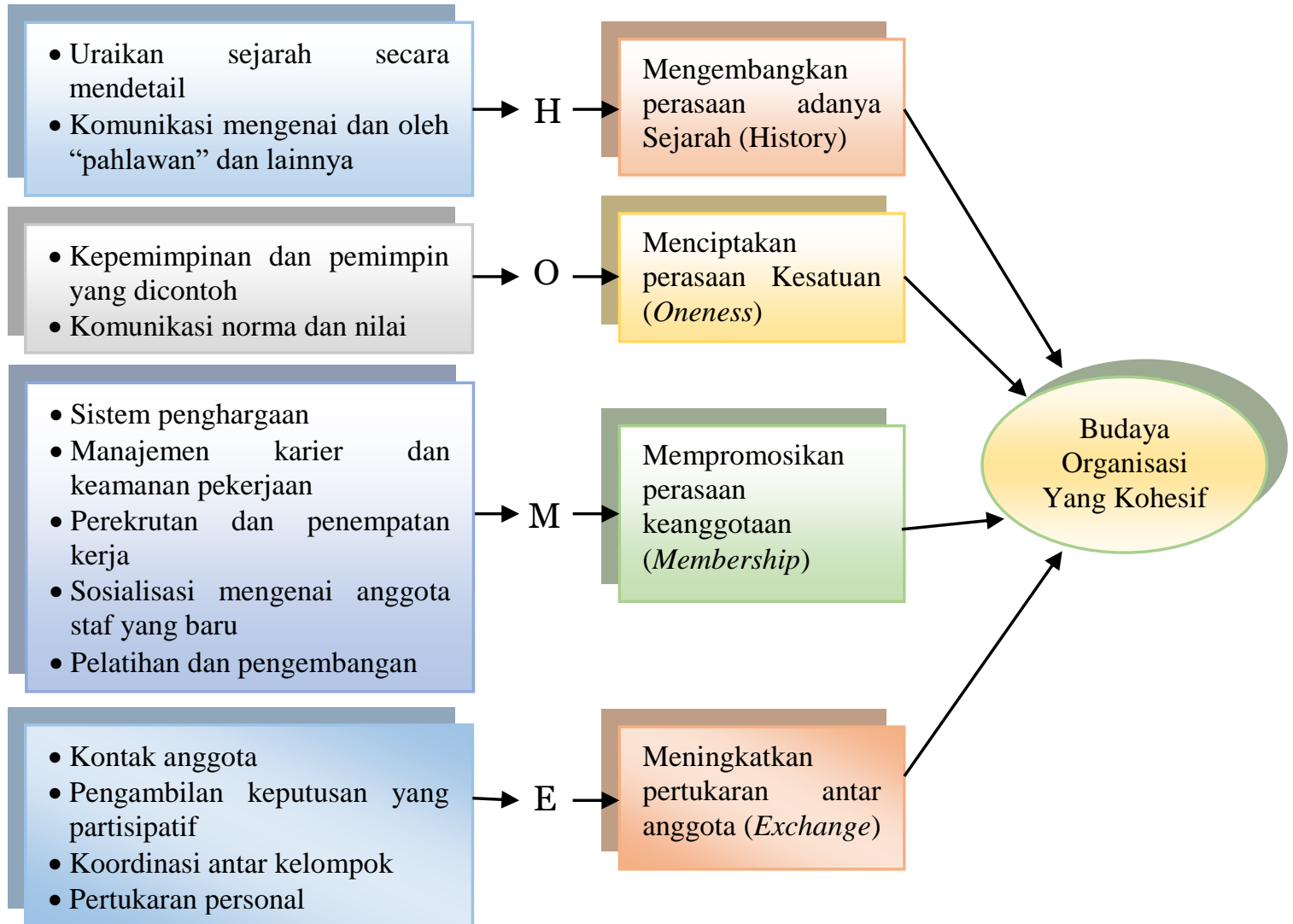

\section{Gambar 1 : Evolusi Budaya Yang Positif Metode Kondisi Yang Diinginkan Hasil}

Komunikasi (communication) adalah proses pertukaran dan pemahaman informasi yang dilakukan oleh dua orang atau lebih, biasanya dengan tujuan memotivasi atau memmengaruhi perilaku. (Richard L. Daft, 2012:418). Lebih lanjut dijelaskan : "Komunikasi bukan hanya untuk menyampaikan informasi, tetapi juga untuk membujuk dan memengaruhi norang lain”.(Richard L. Daft, 2012:425).

George R. Terry dalam Kartini Kartono (2010:47-50), mengatakan : "Sifat pemimpin yang unggul yaitu :

1. Kekuatan badaniah dan rohaniah;

2. Stabilitas emosi;

3. Pengetahuan tentang relasi insani

4. Kejujuran;

5. Objektif;

6. Ketrampilan berkomunikasi;

7. Kemampuan mengajar;

8. Ketrampilan sosial;

9. Kecakapan tehnis dan kecakapan manajerial"

George R. Terry (2012:38), mengatakan : Pengambilan keputusan dapat dilakukan atas dasar : 1. perorangan atau 2. kelompok. Yang pertama biasa dilakukan apabila mudah memutuskannya dan seluruh alternatif mendukung keputusan tersebut. Keputusan perorangan dapat mendukung peranan populer pemimpin. Situasi-situasi darurat umumnya diputuskan secara perorangan. 
Kondisi seperti itu selalu akan timbul; tetapi tidak boleh menilai setiap kondisi sebagai situasi darurat untuk membenarkan pengambilan keputusan secara perorangan. Sedangkan pengambilan keputusan secara kelompok ini semakin populer. Mereka yang terkena oleh suatu keputusan kelompok diberi kesempatan untuk berpartisipasi didalam perumusannya.

Dalam Kamus Bahasa Indonesia pengertian majelis adalah .pertemuan atau perkumpulan orang banyak atau bangunan tempat orang berkumpul. (Departemen Pendidikan dan Kebudayaan, 1999:615). Dari pengertian terminologi tentang majelis ta.lim di atas dapatlah dikatakan bahwa majelis adalah tempat duduk melaksanakan pengajaran atau pengajian agama Islam. Dewan Redaksi Ensiklopedi, 1994:120).

Dalam bahasa Arab kata majelis adalah bentuk isim makan (kata tempat) kata kerja yang artinya .tempat duduk, tempat sidang, dewan. (Ahmad Warson Munawir, 1997:202). Kata ta.lim dalam bahasa Arab merupakan masdar dari kata kerja yang mempunyai arti .pengajaran. (Ahmad Warson Munawir, 1997:1038).

Mengenai tujuan majelis ta.lim, mungkin rumusnya bermacam-macam. Sesuai dengan pandangan ahli agama para pendiri majelis ta'lim dengan organisasi, lingkungan dan jama.ahnya yang berbeda tidak pernah merumuskan tujuannya.

Berdasarkan renungan dan pengalaman Tuty Alawiyah (1997:78), merumuskan : "Tujuan majelis ta.lim dari segi fungsinya, yaitu: pertama, sebagai tempat belajar, maka tujuan majelis ta'lim adalah menambah ilmu dan keyakinan agama yang akan mendorong pengalaman ajaran agama. Kedua, sebagai kontak sosial maka tujuannya adalah silaturahmi. Ketiga, mewujudkan minat sosial, maka tujuannya adalah meningkatkan kesadaran dan kesejahteraan rumah tangga dan lingkungan jama.ahnya”.

M. Habib Chirzin (1997:77), secara spesifik mengatakan bahwa majelis ta'lim yang diadakan oleh masyarakat pesantren-pesantren yang ada di pelosok pedesaan maupun perKotaan adalah:

1. Meletakkan dasar keimanan dalam ketentuan dan semua hal-hal yang gaib;

2. Semangat dan nilai ibadah yang meresapi seluruh kegiatan hidup manusia dan alam semesta;

3. Inspirasi, motivasi dan stimulasi agar seluruh potensi jamaah dapat dikembangkan dan diaktifkan secara maksimal dan optimal dengan kegiatan pembinaan pribadi dan kerja produktif untuk kesejahteraan bersama;

4. Segala kegiatan atau aktifitas sehingga menjadi kesatuan yang padat dan selaras.

H. M. Arifin (1995:323), tujuan majelis ta'lim adalah : mengokohkan landasan hidup manusia Indonesia pada khususnya di bidang mental spiritual keagamaan Islam dalam rangka meningkatkan kualitas hidupnya secara integral, lahiriyah dan batiniyahnya, duniawiyah dan ukhrawiyah secara bersamaan sesuai tuntutan ajaran agama Islam yaitu iman dan takwa yang melandasi kehidupan duniawi dalam segala bidang kegiatannya. Fungsi demikian sejalan dengan pembangunan nasional kita.

Majelis ta'lim bila dilihat dari struktur organisasinya, termasuk organisasi pendidikan luar sekolah yaitu lembaga pendidikanyang sifatnya non formal, karena tidak di dukung oleh seperangkat aturan akademik kurikulum, 
lama waktu belajar, tidak ada kenaikan kelas, buku raport, ijazah dan sebagainya sebagaimana lembaga pendidikan formal yaitu sekolah. (H. Nurul Huda,1987:13)

Dilihat dari segi tujuan, majelis ta.lim termasuk sarana dakwah Islamiyah yang secara self . standing dan self disciplined mengatur dan melaksanakan berbagai kegiatan berdasarkan musyawarah untuk mufakat demi untuk kelancaran pelaksanaan ta.lim Islami sesuai dengan tuntutan pesertanya. Dilihat dari aspek sejarah sebelum kemerdekaan Indonesia sampai sekarang banyak terdapat lembaga pendidikan Islam memegang peranan sangat penting dalam penyebaran ajaran Islam di Indonesia. Di samping peranannya yang ikut menentukan dalam membangkitkan sikap patriotisme dan nasionalisme sebagai modal mencapai kemerdekaan Indonesia, lembaga ini ikut serta menunjang tercapainya tujuan pendidikan nasional. Dilihat dari bentuk dan sifat pendidikannya, lembaga-lembaga pendidikan Islam tersebut ada yang berbentuk langgar, suarau, rangkang. (Zuhairini, dkk,1995:192)

Telah dikemukakan bahwa majelis ta.lim adalah lembaga pendidikan non formal Islam. Dengan demikian ia bukan lembaga pendidikan formal Islam seperti madrasah, sekolah, pondok pesantren atau perguruan tinggi. Ia juga bukan organisasi massa atau organisasi politik. Namun, majelis ta.lim mempunyai kedudukan tersendiri di tengah-tengah masyarakat yaitu antara lain:

1. Sebagai wadah untuk membina dan mengembangkan kehidupan beragama dalam rangka membentuk masyarakat yang bertakwa kepada Allah SWT.

2. Taman rekreasi rohaniah, karena penyelenggaraannya bersifat santai.

3. Wadah silaturahmi yang menghidup suburkan syiar Islam.

4. Media penyampaian gagasan-gagasan yang bermanfaat bagi pembangunan umat dan bangsa. (Dewan Redaksi Ensiklopedi, hal. 1994:123)

Dalam kaitan ini H.M. Arifin (1995:120), mengatakan: "Jadi peranan secara fungsional majelis ta.lim adalah mengokohkan landasan hidup manusia muslim Indonesia pada khususnya di bidang mental spiritual keagamaan Islam dalam upaya meningkatkan kualitas hidupnya secara integral, lahiriah dan batiniahnya, duniawi dan ukhrawiah bersamaan (simultan), sesuai tuntunan ajaran agama Islam yaitu iman dan taqwa yang melandasi kehidupan duniawi dalam segala bidang kegiatannya. Fungsi demikian sejalan dengan pembangunan nasional kita".

Ada berbagai metode yang digunakan di majelis ta'lim, yaitu :

1. Metode Ceramah, yang dimaksud adalah penerangan dengan penuturan lisan oleh guru terhadap peserta.

2. Metode Tanya Jawab, metode ini membuat peserta lebih aktif. Keaktifan dirangsang melalui pertanyaan yang disajikan.

3. Metode Latihan, metode ini sifatnya melatih untuk menimbulkan keterampilan dan ketangkasan.

4. Metode Diskusi, metode ini akan dipakai harus ada terlebih dahulu masalah atau pertanyaan yang jawabannya dapat didiskusikan. (H.M. Arifin, 1995:43-45). 
Metode penyajian majelis ta'lim dapat dikategorikan menjadi:

1. Metode Ceramah, terdiri dari ceramah umum, yakni pengajar/ustadz/kiai tindak aktif memberikan pengajaran sementara jamaah pasif dan ceramah khusus, yaitu pengajar dan jamaah sama-sama aktif dalam bentuk diskusi.

2. Metode Halaqah, yaitu pengajar membacakan kitab tertentu, sementara jamaah mendengarkan.

3. Metode Campuran, yakni melaksanakan berbagai metode sesuai dengan kebutuhan. (Dewan Redaksi Ensiklopedi, 1994:156)

Konsep pendidikan seumur hidup (Life Long Education) mulai dari masyarakat melalui kebijaksanaan Negara (Tap MPR No. IV/MPR/1973 JO. Tap MPR No. IV/MPR/1978, tentang GBHN) menetapkan dalam bab IV bagian pendidikan bahwa .Pendidikan berlangsung seumur hidup dan dilaksanakan di dalam lingkungan rumah tangga, sekolah dan masyarakat. Karena itu pendidikan adalah tanggung jawab bersama antara keluarga, masyarakat dan pemerintah. (Ramayulis, 1994:19)

Menurut bahasa Majelis Ta'lim berasal dari kata bahasa Arab yaitu dari kata majlis yang artinya tempat duduk. yang artinya tempat duduk, dan ta'lim yang artinya pengajaran. Jadi majelis ta.lim adalah tempat untuk mengadakan pengajaran dan pengajian agama Islam. Pengertian majelis lainnya adalah tempat berkumpulnya sekelompok orang untuk melakukan semua kegiatan, sehingga dikenal sebagai majelis semua majelis syuro, majelis hakim dan sebagainya. (Koordinasi Da.wah Islam (KODI) DKI Jakarta, 5:1990). Sedangkan kata ta.lim dapat diartikan mengajar. (Asad M. Kalali 1987:8). Dari beberapa pendapat tentang definisi ta.lim, maka dapat disimpulkan bahwa ta.lim adalah suatu bentuk aktif yang dilakukan oleh orang yang ahli dengan memberikan atau mengajarkan ilmu kepada orang lain. (Koordinasi Da.wah Islam (KODI) DKI Jakarta, 1990:6).

Muzayyin A. Arifin (1991:118) mengatakan : ta'lim adalah bentuk aktif yang dilakukan oleh orang yang ahli dalam memberikan atau mengajarkan ilmu kepada orang lain. Zuhairini dkk (1995:76) mengatakan : Pengertian majelis yang lainnya adalah, .Tempat berkumpulnya sekelompok orang untuk melakukan suatu kegiatan, sehingga dikenal sebagai majelis, seperti majelis syuro, majelis hakim dan lain sebagainya.sedangkan secara istilah pengertian majelis ta'lim adalah, .Organisasi pendidikan luar sekolah (non formal) yang bercirikan keagamaan Islam.

Adapun lembaga-lembaga pendidikan Islam yang ada di Indonesia cukup banyak, diantaranya :

1. Masjid ( surau, langgar, mushalla, dan muanasah);

2. Madrasah dan pondok pesantren;

3. Pengajian dan penerangan Islam (majelis ta'lim);

4. Kursus-kursus keislaman (training);

5. Badan-badan pembinaan rohani;

6. Badan-badan konsultasi keislaman;

7. Musabaqoh tilawatil qur.an. (Hamdani Ali, 1987:203)

Jika membuka lembaran sejarah pendidikan Islam, maka akan kita jumpai lembaga atau institusi Pendidikan Islam yang berjenis-jenis macamnya, semenjak Nabi Muhammad menda.wahkan Islam secara aktif di Mekkah sampai periode abad ke- $8 \mathrm{H}$ telah berdiri dan berkembang lembaga pendidikan Islam antara lain : 
1. Lembaga pendidikan rumah : Dâr al-Arqam;

2. Lembaga pendidikan masjid : Masjidil Haram dan Masjid Nabawi dengan sistem halaqah;

3. Lembaga pendidikan al-Kuttab;

4. Lembaga pendidikan Madrasah yakni : madrasah an-Nizamiyah

5. Madrasah annashiriyah, madrasah Al-Qumhi, As-Safi.iyah, An-Nuriyah (Syiria), madrasah al-Kamiliyah (Mesir), madrasah addahiliyah;

6. Lembaga pendidikan Zawiyah : suatu tempat belajar di masjid.

Pengertian Zawiyah ini meluas sehingga dikenal sebagai tempat belajar yang terpisah dari bangunan masjid yang hampir menyamai fungsi madrasah. Akhirnya berkembang pada abad ke $8 \mathrm{H}$ di negara Maghribi (Afrika Utara), yang akhirnya lembaga pendidikan ini berkembang dalam bentuk formal (Madrasah) semua jenjang sampai dengan Universitas (al Jami.ah) dan bentuk non formal (majelis ta.lim) dan pendidikan individual (langsung dengan guru atau ulama. (M. Arifin, 1994:83-87).

Pendidikan No IV/1950, No XII/1954, dan UU Pendidikan No I/1989 dan berbagai peraturan yang mengatur lembaga-lembaga pendidikan Islam. Penyelenggaraan majelis ta.lim berbeda dengan peyelenggaraan pendidikan Islam lainnya, seperti pesantren dan madrasah, baik menyangkut sistem, materi maupun tujuannya. Menurut penulis pada majelis ta.lim ada hal-hal yang membedakan dari yang lain :

1. Majelis ta.lim adalah lembaga pendidikan non formal Islam;

2. Pengikut atau pesertanya disebut jamâ.ah (orang banyak), bukan pelajar atau santri. Hal ini didasarkan kepada kehadiran di majelis ta.lim tidak merupakan kewajiban sebagaimana dengan kewajiban murid menghadiri sekolah;

3. Waktu belajar berkala tetapi teratur, tidak setiap hari sebagaimana halnya sekolah dan madrasah;

4. Tujuannya yaitu untuk memasyarakatkan ajaran Islam.

Majelis ta.lim adalah lembaga pengajian dan pengajaran agama Islam yang mensyaratkan adanya :

1. Badan yang mengurusi sehingga kegiatan ta.lim tersebut berkesinambungan;

2. Guru, ustadz, muballigh, baik seorang atau lebih yang memberikan pelajaran secara rutin dan berkesinambungan;

3. Peserta atau jama.ah yang relatif tetap;

4. Kurikulum atau materi pokok yang diajarkan;

5. Kegiatannya dilaksanakan secara teratur dan berkala;

6. Adanya tempat tertentu untuk menyelenggarakannya. (M. Arifin, 1994:8991).

Penelitian ini merupakan penelitian kualitatif. penelitian yang dilakukan termasuk dalam penelitian jenis deskriptip kualitatif yaitu model analisis memberi gambaran bagaimana alur logika analisis data. (Suharsimi Arikunto, 1996:83). Lebih lanjut Suharsimi Arikunto (1996:47), mengatakan : "Metode dalam penelitian kualitatif lebih pada penegasan dan penjelasan yang menunjuk pada prosedur-prosedur umum seperti alasan 1 pendekatan tersebut digunakan. 2. unit analisis. 3. metode pengumpulan data dan 4. keabsahan data".

Penelitian ini merupakan penelitian yang berkaitan dengan kegiatan Ibuibu BKMT Kota Jayapura dalam mengembangkan majelis Ta’lim tingkat mesjid 
se-Kota Jayapura, oleh sebab itu menggunakan verba fenomenologi. Penggunaan logika berfikirnya menggunakan asumsi inter subjektifitas ${ }^{2}$, sedangkan verba penelitian kualitatif yang digunakan adalah : Fenomenologis Sosial3. Penelitian ini memusatkan perhatian pada makna dan pengalaman subjektif sehari-hari, yang bertujuan untuk menjelaskan bagaimana objek dan pengalaman tercipta secara penuh makna dan dikomunikasikan dalam kehidupan sehari-hari. Penelitian dilakukan di Sekretariat BKMT Kota Jayapura. Instrumen kunci penelitian adalah Pengurus BKMT Kota Jayapura dalam mengembangkan organisasi keagamaan pada tingkat majelis Ta'lim di Mesjid-mesjid di Kota Jayapura. Untuk menganalisis permasalahan penelitian diperoleh dari dua sumber yaitu : data primer dan data sekunder.

Tehnik memperoleh data : Pertama dengan menggunakan studi kepustakaan. Penelitian kepustakaan merupakan cara mengumpulkan data dan informasi dengan bantuan bermacam-macam materi yang terdapat di ruang perpustakaan. (Kartini Kartono, 1990:27). Penulis memperoleh data atau keterangan sekunder dengan mempelajari sejumlah catatan, buku, karya tulis atau dokumen lainnya yang dianggap mempunyai relevansi dengan masalah yang diteliti. Penelitian ini juga menggunakan tehnik penelitian lapangan yang merupakan penelitian yang dilakukan di lapangan atau lokasi penelitian, dimana peristiwa atau gejala yang menjadi obyek penelitian lapangan atau merupakan lokasi sebagai tempat sumber-sumber data primer dapat ditemukan. (Taliziduhu Ndraha, 1993:115). Untuk mendapatkan data lapangan : Pertama melakukan Observasi Partisipatoris. Dalam kegiatan observasi partisipatoris ini, penulis melakukan kegiatan pemuatan perhatian terhadap sesuatu obyek dengan seluruh panca indra tentang gejala-gejala tertentu dengan jalan mengamati langsung sehingga peneliti mengenal langsung obyek yang diteliti. Kedua melakukan In-depth Interview. Kedalaman wawancara yang dilakukan penulis adalah dialog atau wawancara untuk memperoleh data yang akan diteliti yang didapat dari informan atau nara sumber, dengan lebih bebas, untuk mendapatkan permasalahan lebih terbuka, dengan melakukan wawancara tidak berstruktur. Identitas informan, waktu penelitian dituliskan dalam penelitian ini. Ketiga melakukan sesi Dokumentasi. Penulis mencari sumber data yang akan diteliti dari buku, dokumen, peraturan yang mendukung dalam penelitian, baik berupa catatan harian, gambar atau karya-karya monumental dari seseorang.

Bognan dalam Sugiyono (2010:334), mengatakan “ Analisa data adalah proses mencari dan menyusun secara sistematis data yang diperoleh dari hasil wawancara, catatan lapangan, bahan-bahan lain, sehingga dapat mudah difahami, dan temuannya dapat diinformasikan kepada orang lain". Tehnik analisa data yang digunakan dalam penelitian ini adalah menggunakan tehnik analisa model bagan alir, yang menganalisa data dengan cara membagi dalam

${ }^{2}$ Secara umum menciptakan makna dan realitas antara peneliti dan partisipan. (Norman K. Denzin \& Yvonna S. Lincoln, HandBook of Qualitative Research, Yogyakarta:Pustaka Pelajar, (2009:206))

3Dijelaskan oleh Schutz dan Luckman "Fenomenologi Sosial dimaksudkan untuk merumuskan ilmu sosial yang mampu "menafsirkan dan menjelaskan tindakan dan pemikiran manusia' dengan cara menggambarkan struktur-struktur dasar'....realita yang tampak 'nyata' dimata setiap orang yang berpegang teguh pada 'sikap alamiah'.(Norman K. Denzin dan Yvona. S. Lincoln, 2009:337) 
tiga bagian : Pertama Reduksi Data : Yaitu merangkum data, memilih hal-hal yang pokok, memfokuskan pada hal-hal yang penting, dan membuang hal-hal yang tidak diperlukan; Kedua Data Display (Penyajian Data) : Yaitu membuat uraian singkat, bagan, hubungan antar kategori dan sejenisnya; Ketiga Conclusion Drawing/verification : Yaitu penarikan kesimpulan dan verifikasi. (Sugiyono, 2010:337).

\section{B. PERAN PENGURUS DALAM MENGEMBANGKAN ORGANISASI BKMT KOTA JAYAPURA}

Pentingnya pemahaman anggota pengurus BKMT Kota Jayapura terhadap sejarah berdirinya BKMT Kota Jayapura, hal ini disebabkan karena agar dapat menumbuh kembangkan tentang rasa kebersamaan diantara para anggota pengurus. Tidak semua pengurus BKMT Kota Jayapura mengetahui dengan pasti tentang sejarah berdirinya BKMT Kota Jayapura, yang disebabkan beberapa hal diantaranya adalah tidak tersosialisasinya sejarah berdirinya BKMT Kota Jayapura yang ada pada profil BKMT Kota Jayapura.

Terkadang orang berfikir bahwa komunikasi sangat mudah dan sederhana, namun dalam suatu organisasi komunikasi merupakan suatu yang kompleks sehingga peluang untuk menerima ataupun mengirimkan pesan yang keliru sangatlah banyak jumlahnya. Adanya komunikasi aktif antara anggota dengan pendiri-pendiri BKMT Kota Jayapura sangatlah dibutuhkan dalam rangka mempererat tali silaturahim dan berbagi pengalaman, sehingga apa yang kurang dimasa lalu dapat diperbaiki untuk waktu-waktu yang akan datang. Hal ini sangat dibutuhkan dalam rangka pengembangan BKMT Kota Jayapura kedepannya. Komunikasi (communication) adalah proses pertukaran dan pemahaman informasi yang dilakukan oleh dua orang atau lebih, biasanya dengan tujuan memotivasi atau memmengaruhi perilaku. Dari penjelasan tersebut diatas jika dikaitkan dengan pengertian komunikasi, maka dapat disimpulkan bahwa : Pengurus BKMT Kota Jayapura yang ada pada saat ini tetap melaksanakan komunikasi dengan para pendiri BKMT Kota Jayapura, sehingga proses pertukaran dan pemahaman informasi yang dilakukan antara pengurus yang ada saat ini dengan para pendiri BKMT Kota tetap berjalan.

Kemampuan dalam berkomunikasi sangat dibutuhkan oleh pimpinan organisasi dalam menciptakan iklim kerja yang baik. Tanpa adanya komunikasi yang baik antara pimpinan dengan anggota-anggotanya, maka akan menimbulkan kekacauan dalam organisasi. BKMT Kota Jayapura yang notabenenya adalah sebuah organisasi kewanitaan yang bergerak dibidang keagamaan juga mengharapkan aadanya komunikasi yang efekti antara pimpinan dengan bawahannya/anggotanya. Ada beberapa pimpinan dalam kepengurusan BKMT Kota Jayapura yang memiliki sifat pemimpin yang unggul serta mampu berkomunikasi dengan bawahannya dan mau meluangkan waktunya untuk memberikan berbagai masukan kepada para bawahan guna pengembangan organisasi..

Tak kalah pentingnya dalam suatu organisasi adalah yang berkaitan dengan komunikasi norma dan nilai, dimana ketiga hal tersebut merupakan penentu dalam pengembangan organisasi terlebih dalam hal menciptakan perasaan kesatuan. BKMT Kota Jayapura menerapkan tentang pentingnya 
komunikasi norma dan nilai dalam setiap tindakan para anggotanya baik dalam melakukan kegiatan maupun ketika berada diluar organisasi, karena budaya organisasi melibatkan ekspektasi, nilai dan sikap bersama hal tersebut memberikan pengaruh pada individu, kelompok, dan proses organisasi. Budaya organisasi terhadap anggota menunjukkan bahwa budaya organisasi menyediakan dan mendorong suatu bentuk stabilitas organisasi, tanpa adanya hal tersebut diatas, maka akan timbul perpecahan dalam organisasi tersebut.

Penghargaan kepada anggota yang memiliki kemmpuan kerja yang tinggi adalah pendorong bagi terciptanya motivasi untuk berbuat lebih dalam diri setiap anggota organisasi. Begitu pula yang terjadi di organisasi BKMT Kota Jayapura, dimana para pimpinan telah memberikan penghargaan kepada pengurus-pengurus yang lama, yang telah memberikan sumbangan besar terhadap kemajuan organisasi BKMT. Dalam tubuh organisasi BKMT Kota Jayapura tidak terdapat apa yang dinamakan penghargaan bagi pengurus yang memiliki sumbangan besar terhadap organisasi tersebut, hal ini disebabkan berbagai pertimbangan yang ada diantaranya yaitu tujuan dibentuknya BKMT itu sendiri merupakan organisasi kemasyarakatan yang bergerak dibidang pemberdayaan kaum muslimah di Kota Jayapura.

Pentingnya management karier dan keamanan pekerjaan dalam suatu organisasi merupakan suatu tuntutan agar terjadi regenerasi dalam suatu organisasi sedangkan keamanan dalam pekerjaan bukan hanya berkisar pada keamanan fisik dari anggota-anggota yang melaksanakan pekerjaan, melainkan pula keamanan dalam hal administrasi perkantoran misalkan membuat dan menyampaikan surat, serta dalam hal keuanagn organisasi. Organisasi BKMT Kota Jayapura melaksanakan keamanan pekerjaan dalam bidang tata persuratan serta dalam membuat proposal kegiatan untuk dapat meminimalisir setiap kesalahan yang mungkin saja dapat timbul. Untuk management karier, berhubung organisasi ini hukanlah organisasi yang birokrasi namun tetap melaksanakan apa yang dinamakan pergantian kepemimpinan sampai dengan masa baktinya, sehingga anggota-anggota dibawahnya dapat pula menggantikan jabatan-jabatan tersebut.

Perekruitan dan penempatan kerja merupakan hal yang biasa dilakukan dalam suatu organisasi karena tanpa adanya perekrutan dan penempatan kerja sulit kiranya melakukan regenerasi terhadap organisasi yang dijalankan sehingga pengetahuan yang ada pada orang-orang terdahulu tidak dapat dilanjutkan pada generasi berikutnya. Dalam organisasi BKMT Kota Jayapura terdapat penempatan pekerjaan atau pembagian tugas bagi setiap anggotanya. BKMT Kota Jayapura juga melaksanakan merencanakan tenaga pengurus, mengidentifikasikan pekerjaan, juga menempatkan anggota-anggota baru yang diambil dari BKMT-BKMT tingkat distrik, kemudian diberikan pekerjaan sesuai dengan keahlian yang dimilikinya. Jika terdapat anggota baru dalam suatu organisasi hendaknya memberikan sosialisasi agar ia mampu beradaptasi dengan lingkungan dan anggota organisasi lainnya. Begitu pula dengan BKMT Kota Jayapura, dimana setiap ada anggota baru maka perlu dialakukan sosialisasi agar mampu beradaptasi dengan lingkungan barunya tersebut. BKMT Kota Jayapura melaksanakan apa yang dinamakan sosialisasi terhadap kedatangan anggota pengurus barunya, mulai dari perkenalan dengan pengurus-pengurus lama sampai dengan perkenalan dengan tugas dan tanggungjawab yang harus dilaksanakan oleh pengurus baru tersebut. 
Pendidikan, pelatihan dan pengembangan adalah salah satu pembinaan tenaga kerja disamping adanya upaya yang lain, hal ini dilakukan dalam rangka meningkatkan kemampuan sumber daya manusia dalam melaksanakan tugasnya. Pengurus BKMT Kota Jayapura juga melaksanakan pelatihan dan pengembangan anggota pengurus. Pelatihan-pelatihan dan pengembangan yang dilakukan untuk para pengurus BKMT Kota Jayapura masih terkendala dengan adanya sumber dana yang tersedia, dimana jika terdapat sumber dana yang cukup, BKMT Kota Jayapura melakukan pelatihan-pelatihan dengan mengundang para ahli dan mengundang pula peserta dari BKMT tingkat distrik, namun tidak jarang BKMT Kota Jayapura menerima undangan untuk mengikuti pelatihan yang dilakukan oleh lembaga-lembaga lainnya.

Dalam suatu oraganisasi dibutuhkan adanya adanya komunikasi interpersonal antar anggota, dimana tanpa adanya hal tersebut diatas, maka dapat dikatakan bahwa birokrasi tidak dapat berjalan sebagaimana mestinya. Dalam organisasi BKMT Kota Jayapura juga diwajibkan untuk melakukan kontak antar anggota sehingga setiap pekerjaan mampu dilaksanakan secara baik dan benar dengan bantuan anggota-anggota lainnya, dimana proses administrasi harus dilaksanakan bukanlah oleh satu orang saja, melainkan dilakukan oleh lebih dari satu orang. Kontak antara pengurus BKMT Kota Jayapura sering dilakukan dan antar pengurus saling mengenal antara satu dengan yang lainnya sehingga memudahkan bagi setiap pengurus saling berhubungan satu dengan yang lainnya.

Pengambilan keputusan merupakan inti dari kepemimpinan, oleh karena itu setiap pemimpin dalam organisasi baik tingkat low managerial ataupun top managerial dalam suatu organisasi hendaklah memiliki kemampuan dalam mengambil keputusan. Tanpa adanya kemampuan dalam mengambil keputusan, maka sulit untuk memecahkan suatu masalah yang ada dalam suatu organisasi. Dalam BKMT Kota Jayapura terdapat pengambilan keputusan yang dilakukan secara perorangan, namun ada juga yang dilakukan secara kelompok, dimana pengambilan keputusan yang dilakukan oleh pimpinan BKMT mungkin berdasarkan pertimbangan-pertimbangan tertentu, atau berdasargan sifat urgennya.

Pentingnya koordinasi antar kelompok dalam suatu organisasi adalah sangat penting dan sangat berpengaruh terhadap pengembangan suatu organisasi. Tanpa adanya koordinasi antara kelompok suatu organisasi sangatlah sulit mencapai tujuan yang diharapkan. Begitu pula yang terjadi dengan organisasi BKMT Kota Jayapura dimana mereka melakukan koordinasi dengan kelompok-kelompok baik diatasnya yaitu BKMT Propinsi maupun kelompok-kelompok dibawahnya yaitu BKMT cabang atau Distrik, untuk memperoleh informasi dan melakukan kerjasama yang lebih erat berkaitan dengan pengembangan organisasi. Koordinasi hanya dilakukan jika terdapat pekerjaan yang dilakukan secara bersama-sama namun dalam hal pekerjaan yang tidak melibatkan berbagai bidang pekerjaan koordinasi hanya berlangsung di bidang-bidangnya masing-masing dibawah ketua bidangnya masing-masing.

Kebutuhan akan pertukaran personal merupakan suatu penyegaran dalam organisasi, dan merupakan peningkatan keahlian diantara personal, hal ini disebabkan karena dengan adanya roling antara anggota dapat menambah pengalaman dan pengetahuan dari setiap anggota. Seperti halnya yang terjadi di dalam organisasi BKMT Kota Jayapura dimana dilakukan pertukaran 
personal. BKMT Kota Jayapura melaksanakan pertukaran personal baik diantara pengurus yang ada dalam tubuh BKMT Kota maupun dengan pengurus yang ada di propinsi atau BKMT yang ada pada tingkat distrik.

\section{METODE, BENTUK KEGIATAN-KEGIATAN DAN FAKTOR- FAKTOR PENGHAMBAT DARI KEGIATAN YANG DILAKUKAN OLEH BKIMT KOTA JAYAPURA}

Setiap kegiatan yang dilakukan oleh suatu organisasi biasanya melalui suatu perencanaan, baikm perencanaan jangka panjang ataupun perencanaan jangka pendek. Perencanaan tersebut disusun dengan maksud agar suatu organisasi mampu berjalan sesuai dengan tujuan yang diharapkan. Namun terkadang apa yang telah direncanakan tersebut tidak dapat diwujudkan dalam sebuah kenyataan. Tanpa adanya kegiatan yang dilaksanakan oleh suatu organisasi maka dapat dikatakan organisasi tersebut dalam keadaan vakum dan dianggap jalan ditempat atau bahkan dapat mencapai suatu tahap kemunduran dari organisasi tersebut.BKMT Kota Jayapura yang merupakan organisasi yang mewadahi ibi-ibu muslimah diwilayah Kota Jayapura, yang bergerak dibidang keagamaan (Islam) dimana dalam melaksanakan aktifitasnya mengacu pada program kerja yang telah disusun secara bersama oleh para anggotanya, sehingga program kerja tersebut merupakan acuan dalam melaksanakan kegiatan/aktifitas organisasi. BKMT Kota Jayapura dalam melakukan pembinaan keagamaan kepada Majelis Ta'lim tingkat distrik dan tingkat masjid se Kota Jayapura masih berfokus pada penggunaan metode ceramah keagamaan walaupun terdapat metode-metode lain yang digunakan namun sangat jarang sekali penggunaannya. Perlu pengembangan metode pembinaan keagamaan yang dilakukan oleh BKMT Kota Jayapura yang lebig bervariasi sehingga tidak membosankan dalam penyajian pembinaan keagamaan kepada majelis taklim tingkat mesjid..

Betapa kompleksnya kegiatan dalam suatu organisasi menggambarkan bahwa betapa besar dan beragamnya pekerjaan yang dilakukan dalam organisasi tersebut. Ada berbagai kegiatan yang sering dilakukan oleh pengurus BKMT Kota Jayapura dalam melaksanakan tugasnya, diantaranya adalah kegiatan-kegiatan sosial kemasyarakatan. BKMT Kota Jayapura juga melaksanakan kegiatan-kegiatan bakti sosial yang difokuskan pada tempattempat yang masih sangat membutuhkan baik bantuan dana maupun bantuanbantuan lainnya baik dilakukan diwilayah-wilayah yang masuk dalam lingkup Kota Jayapura, ataupun wilayah-wilayah lain di propinsi Papua diluar wilayah Kota Jayapura.

Peran BKMT Kota Jayapura sangat dibutuhkan oleh umat muslim di Kota Jayapura dengan berbagai aktifitas yang dilakukannya diharapkan mampu memberikan nilai lebih bagi masyarakat muslim Kota Jayapura. Namun terkadang tidak mudah untuk merealisasikan apa yang diharapkan oleh majelis Taklim tingkat masjid terhadap peran yang dilakukan oleh BKMT Kota Jayapura. Peran BKMT Kota Jayapura dirasakan belum secara menyeluruh mampu dirasakan oleh pengurus majelis taklim tingkat mesjid,

Ada berbagai faktor penyebab dari hambatan-hambatan yang sering dialami dalam suatu kegiatan yang dilakukan oleh suatu organisasi, begitu pula 
yang dialami oleh BKMT Kota Jayapura, dimana dalam melaksanakan berbagai kegiatan sering mengalami hambatan-hambatan, diantaranya dapat dikelompokkan menjadi dua bagian yaitu : hambatan yang dipengaruhi oelh faktor eksternal dan faktor internal. Adapun faktor-faktor tersebut diatas dapat dijelaskan sebagai berikut : Faktor internal merupakan faktor yang muncul dan mempengaruhi terjadinya perubahan-perubahan baik positif maupun negatif yang muncul dari dalam diri organisasi. Akibat dari keterbatasan sumber dana yang dimiliki BKMT Kota Jayapura, muncul perbedaan antara das solen dengan das sein (harapan dengan kenyataan), juga akibat pendataan jumlah Majelis Ta'lim yang ada di Kota Jayapura yang semakin lama semakin bertambah, sehingga apa yang telah direncanakan dalam program kerja pengurus tidak mampu untuk direalisasikan. Disamping faktor internal tersebut diatas, terdapat pula faktor eksternal yaitu faktor-faktor yang muncul dari luar organisasi BKMT Kota Jayapura dalam melaksanakan berbagai kegiatannya. Faktor eksternal yang mempengaruhi terhambatnya berbagai kegiatan dalam organisasi BKMT Kota Jayapura adalah dipengaruhi oleh luasnya wilayah Kota Jayapura sehingga masih ada wilayah-wilayah yang belum mampu di Jangkau oleh BKMT Kota Jayapura, disamping itu tidak seluruh Majelis Ta'lim tingkat Mesjid terdaftar di BKMT Kota Jayapura, sehingga menyulitkan BKMT Kota Jayapura dalam mengundang Majelis Taklim tersebut dalam melaksanakan kegiatan secara bersama-sama.

Dari berbagai kegiatan yang dilaksanakan oleh BKMT Kota Jayapura yang tertuang dalam program kerja BKMT Kota Jayapura, memberikan harapan kepada Majelis Ta'lim tingkat Mesjid. Kurangnya kegiatan-kegiatan yang berdampak pada pengembangan pengetahuan keagamaan yang dilakukan oleh BKMT Kota Jayapura maupun BKMT tingkat distrik yang melibatkan Majelis Ta'lim tingkat Mesjid serta keterwakilan pengurus yang belum merata dari setiap Mesjid yang memiliki kelompok Majelis Ta'lim, sehingga perlu adanya pengkajian ulang terhadap program kerja utama serta struktur kepengurusan yang harus dilakukan BKMT Kota Jayapura, sehingga mampu memberikan rangsangan terhadap setiap kegiatan yang dilakukan BKMT Kota Jayapura serta mampu mencapai tujuan yang diharapkan.

\section{KESIMPULAN}

Pengurus BKMT Kota Jayapura melakukan pemahaman kepada anggota tentang sejarah berdirinya BKMT Kota Jayapura. Melaksanakan komunikasi dengan pendiri BKMT Kota Jayapura sehingga pertukaran dan pemahaman informasi yang dilakukan antara pengurus dengan pendiri BKMT Kota berjalan. Adanya pemimpin yang dijadikan panutan, pentingnya komunikasi norma dan nilai dalam tindakan anggotanya baik dalam melakukan kegiatan ketika berada diluar organisasi. Tidak adanya penghargaan bagi pengurus yang memiliki sumbangan besar terhadap organisasi. Melaksanakan keamanan pekerjaan dalam bidang tata persuratan, dalam membuat proposal kegiatan untuk meminimalisir kesalahan. Merencanakan tenaga pengurus, mengidentifikasikan pekerjaan, menempatkan anggota baru yang diambil dari BKMT tingkat distrik, kemudian diberikan pekerjaan sesuai keahlian yang dimilikinya. Melaksanakan sosialisasi pada anggota pengurus baru, mulai dari perkenalan dengan pengurus 
lama, tugas, tanggungjawab yang harus dilaksanakan pengurus baru. Pelatihan dan pengembangan yang dilakukan untuk pengurus BKMT Kota Jayapura terkendala sumber dana yang tersedia, jika terdapat sumber dana cukup, BKMT Kota Jayapura melakukan pelatihan, mengundang ahli dan peserta dari BKMT tingkat distrik, namun tidak jarang BKMT Kota Jayapura menerima undangan untuk mengikuti pelatihan yang dilakukan lembaga lainnya. Kontak antara pengurus BKMT Kota Jayapura sering dilakukan dan antar pengurus saling mengenal sehingga memudahkan pengurus saling berhubungan. Terdapat pengambilan keputusan yang dilakukan secara perorangan, juga dilakukan secara kelompok, pengambilan keputusan yang dilakukan pimpinan BKMT berdasarkan pertimbangan tertentu, atau berdasarkan sifat urgennya. Koordinasi dilakukan jika terdapat pekerjaan yang dilakukan secara bersama, melaksanakan pertukaran personal diantara pengurus yang ada dalam BKMT Kota maupun dengan pengurus yang ada di propinsi atau BKMT yang ada pada tingkat distrik. Berfokus pada penggunaan metode ceramah keagamaan, melaksanakan kegiatan bakti sosial yang difokuskan pada tempat yang membutuhkan baik bantuan dana maupun bantuan lainnya baik dilakukan di wilayah yang masuk dalam lingkup Kota Jayapura, ataupun wilayah lain di propinsi Papua diluar Kota Jayapura. Faktor internal akibat keterbatasan sumber dana yang dimiliki BKMT Kota Jayapura, muncul perbedaan antara harapan dengan kenyataan, akibat pendataan jumlah Majelis Ta'lim yang ada di Kota Jayapura yang semakin bertambah, sehingga apa yang telah direncanakan dalam program kerja pengurus tidak mampu direalisasikan. Faktor eksternal : dipengaruhi luasnya wilayah Kota Jayapura sehingga masih ada wilayah yang belum mampu di jangkau BKMT Kota Jayapura. Tidak seluruh Majelis Ta'lim tingkat Mesjid terdaftar di BKMT Kota Jayapura, sehingga menyulitkan BKMT Kota Jayapura dalam mengundang Majelis Ta'lim dalam melaksanakan kegiatan secara bersama.

Saran dari peneliti sebagai berikut : BKMT Kota Jayapura dalam melaksanakan kegiatannya untuk lebih mengikutsertakan Majelis Ta'lim tingkat di bawahnya. BKMT Kota Jayapura hendaknya lebih mengedepankan kegiatan yang bersifat pengembangan pengetahuan keagamaan bagi Majelis Ta'lim di Kota Jayapura. Bagi Kementerian Agama Republik Indonesia hendaknya memberikan dukungan dana kegiatan oraganisasi BKMT dimanapun berada agar kegiatan dapat mencapai tujuan yang diharapkan. Dapat melakukan penelitian pengulangan (Replicable) lebih mendalam tentang BKMT Kota Jayapura lebih komprehensif agar dapat memperoleh data beragam tentang BKMT Kota Jayapura sehingga memberikan masukan tentang kegiatan yang mampu direalisasikan BKMT Kota Jayapura sehingga menjadi bahan referency yang otentik guna melakukan kajian-kajian tentang BKMT Kota Jayapura. 


\section{DAFTAR PUSTAKA}

\section{Buku}

Alawiyah, Tuti. (1997). Strategi Dakwah di Lingkungan Majelis Ta'lim. Bandung: Mizan.

Ali, Hamdani. (1987). Filsafat Pendidikan. Yogyakarta: Kota Kembang.

Arikunto, Suharsimi. (1996). Prosedur Penelitian Suatu Pendekatan Praktek. Yogyakarta: Renika Cipta.

Arifin, M. H. (1995). Kapita Selekta Pendidikan Islam. Jakarta: Bumi Aksara.

Arifin, M. (1994). Filsafat Pendidikan Islam. Jakarta: Bumi Aksara.

A. Arifin Muzayyin. (1991). Kapita Selekta Pendidikan. Jakarta: Bumi Aksara.

Chirzin, M. Habib. (1997). Pesantren dan Pembaharuan. Jakarta: LP3ES.

Daft, L. Richard. (2012). Era Baru Manajemen. Jakarta: Salemba Empat.

Denzin, K. Norman, \& Lincoln Yvona. S. (2009). HandBook Of Qualitative Research. Yogyakarta: Pustaka Pelajar.

Departemen Pendidikan dan Kebudayaan. (1999). Kamus Besar Bahasa Indonesia. Jakarta: Pustaka.

Dewan Redaksi Ensiklopedi. (1994). Ensiklopedi Islam. Jakarta: Ichtiar Baru Van Hoeve.

Ivancevich, Jhon., Robert, M. Konopaske., \& Michael, Matteson T. (2006). Perilaku Dan Manajemen Organisasi. Jakarta: Erlangga.

Kartini, Kartono. (1990). Pengantar Methodologi Research. Bandung: Alumni.

Kalali, M. Asad. (1987). Kamus Arab Indonesia. Jakarta: Bulan Bintang.

Koordinasi Dakwah Islam (KODI) DKI. (1990). Pedoman Majelis Taklim. Jakarta: cet. ke-2.

Munawir, Ahmad Warson. (1997). Al-Munawir, Kamus Bahasa Indonesia. Yogyakarta: Pustaka Progresif.

Ndraha, Taliziduhu. (1993). Research, Teori Methodologi Administrasi. Jakarta: Bina Aksara.

Nurul, H. Huda (e.d.). (1987). Pedoman Majelis Taklim. Jakarta: Koordinasi Dakwah Islam (KODI).

Ramayulis. (1994). Ilmu Pendidikan Islam. Jakarta: Kalam Mulia.

Sugiyono. (2010). Methode Penelitian Pendidikan, Pendekatan Kuantitatif, Kualitatif, dan R \& D. Bandung: Alfa Beta.

Terry, R. George. (2012). Prinsip-Prinsip Manajemen. Jakarta: Bumi Aksara.

Zuhairini. (1995). Sejarah Pendidikan Islam. Jakarta: Bumi Aksara.

\section{Jurnal dan lainnya}

Khodijah, Nyanyu. (2019). Majelis Taklim Asy Syifa: Potret Majelis Taklim Dalam Komunitas Muslim Muallaf Di Bali. Jurnal Sosial dan Keagamaan IAIN Metro. http: //dualmode. kemenag.go.id/acis11/file/dokumen/ d14.NyayuKhodijah.pdf.

Khoir, Dian Amalia. (2011). Pembinaan Keagamaan Bagi Ibu-ibu Melalui Majelis Ta'lim di Desa Ngijo Kecamatan Karangploso Kabupaten Malang. Universitas Islam Negeri (UIN). http://lib.uin-malang.ac.id/thesis/ introduction/o7110131-dian-khoir-amalia.pdf. 